\title{
PENDIDIKAN BENCANA DAN RESPON PSIKOSOSIAL PADA GURU DI DESA TEMPUR,
} KABUPATEN JEPARA

\author{
Mochamad Widjanarko \\ Fakultas Psikologi Universitas Muria Kudus \\ m.widjanarko@umk.ac.id \\ Dian Wismar'ein \\ Fakultas Ekonomi Universitas Muria Kudus
}

\begin{abstract}
Abstrak
Pegunungan Muria merupakan salah satu kawasan dataran tinggi di bagian Utara Jawa Tengah. Saat ini masih menghadapi berbagai permasalahan lingkungan. Tercatat pada tanggal 20 Maret 2006 terjadi tanah longsor dan banjir bandang di Desa Tempur Kabupaten Jepara yang menyebabkan sekitar 4.000 penduduk terisolasi. Dua jalur utama menuju Desa Tempur, dari Pati maupun Jepara, juga tak bisa dilalui. Sulitnya akses keluar ke desa berikut menjadikan ketersediaan pangan menjadi persoalan paling serius di desa saat itu. Kejadian lagi, pada awal tahun 2014, curah hujan yang tinggi menjadikan longsor dan mengakibatkan sebelas rumah rusak dan terdapat dua retakan tanah ambles di Giligumuk, Dukuh Karangrejo dan Sawah Bongkor di Dukuh Perkoso dan menjadikan sekitar 873-an warga di evakuasi di desa terdekat.

Tujuan dari laporan penelitian tentang efektivitas pengabdian masyarakat ini adalah memberikan pendampingan pada guru MI Al-Anwar dan MTs Mathali'ul Huda di Desa Tempur, Kabupaten Jepara dalam pelatihan pendidikan bencana dan respon psikososial serta pembuatan buku pendidikan bencana. Metode yang digunakan dalam kegiatan ini adalah ceramah, diskusi kelompok terarah, curah pendapat, dan tanya jawab.

Simpulannya adalah guru di MI Al-Anwar dan MTs Mathali'ul Huda telah mendapatkan keahlian untuk mengenal ancaman bencana yang ada di daerahnya dan bisa memiliki kemampuan mengurangi tekanan psikologis pada siswa-siswi yang tinggal di daerah rawan bencana, seperti di Desa Tempur, Kabupaten Jepara serta guru di MI Al-Anwar dan MTs Mathali'ul Huda di Desa Tempur, Kabupaten Jepara telah membuat buku pendidikan bencana.
\end{abstract}

Kata kunci: pendidikan bencana, respon psikososial,buku pendidikan bencana.

\begin{abstract}
Muria Mountains is one of the highlands in the northern part of Central Java and currently faces various environmental problems. Recorded on March 20, 2006 there was a landslide and flash flood in Tempur Village, Jepara then causing 4,000 residents were isolated. The two main routes to Tempur Village; from Pati and Jepara; were are impassable. The difficulty of getting out from the village made the food availability became the most serious problem. In early 2014, high rainfall caused landslides and eleven houses damaged and there were two cracks in Giligumuk, Dukuh Karangrejo and Bongkorrice fields in Dukuh Perkoso and made about 873 residents were is evacuated to nearby villages.

The purpose of this research report on the effectiveness of community service is was to provide accompaniment to MI Al-Anwar and MTs Mathali'ul Huda teachers in Tempur Village, Jepara in disaster education training and psychosocial responding and also creating disaster education book. The methods used in this activity were lectures, focus group discussions, brainstorming, question and answer

The conclusion is that MI Al-Anwar and MTs Mathali'ul Huda teachers gained their expertise to recognize the existing disaster threats in their area and were able to have the ability to reduce the psychological pressure on their students living in disaster-prone areas such as in Tempur Village, Jepara. Then MI Al-Anwar and MTs Mathali'ul Huda teachers in Tempur Village, Jepara have made a disaster education book.
\end{abstract}

Keywords: disaster education, psychosocial responding, disaster education book

(C) 2016 Universitas Muria Kudus 


\section{PENDAHULUAN}

Bencana yang ada di Indonesia telah banyak terjadi seperti gunung meletus,gempa bumi, tsunami, banjir, angin topan, dan tanah longsor. Bencana ini terjadi karena berbagai sebab antara lain adanya dua jalur pegunungan yaitu Pegunungan Sirkum Pasifik dan Sirkum Mediterania di wilayah Indonesia yang menyebabkan banyak gunung berapi. Aktivitas gunung berapi menyebabkan terjadinya gempa vulkanik, sedangkan pergeseran lempeng benua menyebabkan gempa tektonik. Bila pusat gempa terjadi di lautan maka akan terjadi badai tsunami. Iklim di Indonesia menyebabkan angin musim yang kadang-kadang bisa menjadi angin topan, sedangkan curah hujan yang terjadi menyebabkan banjir dan tanah longsor. Dengan adanya banyak bencana, pemerintah melakukan upaya untuk Pengurangan Resiko Bencana (PRB). PRB harus disosialisasikan pada masyarakat Indonesia. PRB sudah diperkuat dengan dikeluarkan undang-undang tentang penganggulangan bencana, namun demikian belum dipahami secara optimal oleh masyarakat. (BNPB, 2010).

Pegunungan Muria merupakan salah satu kawasan dataran tinggi di bagian Utara Jawa Tengah. Saat ini masih menghadapi berbagai permasalahan lingkungan. Secara biofisik kawasan ini mempunyai persoalan berupa kerusakan dan perambahan hutan lindung dan kerusakan lahan pertanian penduduk akibat praktek pengolahan lahan yang tidak ramah lingkungan. Hutan di kawasan ini mengalami tekanan yang berat. Luas hutan lindung Gunung Muria yang masuk Kabupaten Kudus 1.148,59 hektare, 1.228,98 ha (hutan produksi), dan lahan di luar kawasan hutan 39.861,64 ha. Sedang hutan lindung yang masuk wilayah Kabupaten Jepara meliputi 6.615,45 ha, 6.159,63 ha (kawasan konservasi), 6.248,67 ha (hutan produksi), 1.072,76 ha (hutan produksi terbatas), dan lahan di luar kawasan hutan $85.660,91$ ha. Serta hutan lindung di Kabupaten Pati 3.339,08 ha, hutan produksi 20.468,14, dan lahan di luar kawasan hutan 133.574,36 ha. Data Balai Pemantapan Kawasan Hutan (BPKH) Wilayah XI Jawa-Madura tahun 2003 menyebutkan 38.308 ha terindikasi hutan yang mengalami kerusakan, detailnya meliputi: 13.252 ha hutan yang berada dalam kabupaten Jepara, 23.807 ha berada di kawasan Pati dan 1.249 ha berada di kabupaten kudus (Suara Merdeka, 21 September 2004).

Tercatat pada tanggal 20 Maret 2006 terjadi tanah longsor dan banjir bandang di Desa Tempur Kabupaten Jepara menyebabkan sekitar 4.000 penduduk Desa Tempur, Kecamatan Keling, Kabupaten Jepara, terisolasi. Dua jalur utama menuju Desa Tempur, dari Pati maupun Jepara, juga tak bisa dilalui. Sulitnya akses keluar dari lokasi kejadian ke desa lainnya menjadikan ketersediaan pangan menjadi persoalan paling serius di desa tersebut. Warga desa itu tinggal di enam dukuh, yakni Dukuh Kemiren, Petung, Duplak, Pekoso, Glagah dan Karangrejo. Dari pantauan Selasa (21/3-2006), dari arah Desa Jlegong-Damarwulan, Kecamatan Keling, setidaknya ada delapan titik jalan utama menuju desa yang tertimbun 
longsoran. Tiap titik, tertutup longsoran tanah, kayu, dan bongkahan batu besar sejauh antara 50-100 meter.

Gunawan, mantan Kades Desa Tempur mengatakan,"Tidak ada satu pun korban jiwa dalam bencana alam paling buruk dalam 60 tahun terakhir di Tempur. Namun kerugian materi sangat besar. Empat rumah di desa itu hanyut tak berbekas, termasuk satu kios dan rumah makan yang ada di pinggir Sungai Gelis. Selanjutnya Gunawan mengatakan, "Banjir bandang disertai longsoran itu terjadi selama tiga jam, mulai pukul 10:00-13:00. Air sangat besar dengan membawa kayu, batu-batu besar, dan sampah. Suaranya bergemuruh, sehingga warga yang hendak memanen padi di sawah pinggir sungai berlari ke daerah lebih tinggi untuk menyelamatkan diri. Kejadian itu sangat mengerikan." Kepala Dinas Pekerjaan Umum (DPU) Ir. Sholih, MM. mengkalkulasi kerugian materi akibat bencana itu mencapai Rp. 9 miliar.

Kejadian lagi, pada awal tahun 2014, curah hujan yang tinggi menjadikan banjir di Desa Batukali dan Mayong, Kabupaten Jepara. Longsor terjadi di Desa Bate Gede dan Desa Bungu, Kabupaten Jepara. Di Desa Tempur, longsor mengakibatkan sebelas rumah rusak dan saat ini terdapat dua retakan tanah ambles di Giligumuk, Dukuh Karangrejo dan Sawah Bongkor di Dukuh Perkoso yang mengakibatkan sekitar 873-an warga di evakuasi di desa terdekat (Widjanarko dkk, 2014).

Kerugian fisik dari gagal panen, kerusakan infrastruktur dan harta pribadi. Belum lagi kerugian nonfisik yang tak terhitung. Kondisi psikologis pasca bencana dari korban sendiri belum diperhitungkan. Pasca bencana, pihak pemerintah, pemerhati lingkungan dan masyarakat korban tekesan saling menyalahkan.

Salah satu penyebab banyaknya korban harta dan psikis adalah kekurangsiapan masyarakat dalam mengantisipasi bencana. Risiko bencana sebagai dampak buruk salah kelola dan salah urus tersebut menyebabkan kelompok masyarakat selalu menjadi korban ketika diperhadapkan pada frekuensi bencana yang terus meningkat pada beberapa tahun terakhir ini. Coping masyarakat dalam pengurangan risiko bencana pun belum menjadi jawaban pasti dalam pengurangan risiko bencana pada hulu, tengah, maupun hilir di kawasan Hutan Muria. Mengenali ancaman kerentanan dan kemampuan menghadapi bencana pun menjadi berbeda-beda. Belum ada intervensi yang bisa dikatakan 'baik' dalam memperkuat masyarakat menghadapi risiko bencana jika prasyarat utama tidak dipersiapkan dengan baik (Widjanarko dan Nugroho, 2010).

Dalam kajian psikologi lingkungan, diprediksi asumsi adanya tahapan perubahan perilaku yang bisa terjadi, manakala individu manusia dewasa mengalami sendiri keadaan tanpa air bersih, menghirup udara busuk, kehilangan hawa sejuk di lingkungan tempat tinggalnya atau secara traumatis yaitu menjadi salah satu korban yang diakibatkan bencana lingkungan maka individu tersebut akhirnya akan dapat berpikir bahwa sesungguhnya bencana-bencana alam yang berasal dari aktivitas manusia diakibatkan perilakunya dirinya 
yang kontra ekologis atau berasal dari manusia dewasa lainnya yang tidak memiliki kepedulian dalam pelestarian lingkungan sehingga menjadikan dirinya menjadi: masyarakat korban (Widjanarko, 2012).

Permasalahan yang dihadapi oleh guru-guru di Desa Tempur, Kabupaten Jepara belum memiliki pemahaman mengenai pendidikan bencana dan melakukan respon psikososial. Padahal seharusnya guru sebagai fasilitator bagi siswa-siswi bisa mengembangkan pendidikan bencana di Desa Tempur yang merupakan daerah yang rawan bencana.

Pendidikan bencana untuk mengurangi risiko bencana di masa anak-anak dan remaja menjadi sangat penting. Pengenalan awal bencana dan kemanfaatan hutan serta ekosistem yang ada di lingkungan sekitar rumah tempat tinggal anak-anak dan remaja yang rawan bencana merupakan 'media nyata' yang bisa digarap dan diberikan untuk para generasi muda.

\section{Tinjauan Pustaka}

Pendidikan lingkungan hidup adalah suatu proses yang bertujuan untuk membangun manusia yang sadar terhadap lingkungan dan segala permasalahan yang berkaitan dengannya, serta memiliki pengetahuan, ketrampilan, sikap dan komitmen untuk dapat memecahkan masalah lingkungan saat ini (Nirarita, 1999).

Pendidikan lingkungan hidup yang diharapkan sebagai wahana bagi pembinaan perubahan paradigma dalam pembentukan perilaku lingkungan bertanggungjawab masih menghadapi kendala. Kendala itu antara lain, masih terdapat pemahaman tentang makna pendidikan yakni masih sebatas transfer of knowledge, sehingga penguasaan materi masih merupakan hal yang penting dibandingkan dengan perubahan sikap apalagi perubahan perilaku.

Pendidikan lingkungan hidup merupakan pembelajaran yang dilakukan untuk membantu peserta didik dalam memahami lingkungan hidup dengan tujuan akhir untuk meningkatkan perlindungan dan sikap bertanggungjawab terhadap lingkungan hidup. Tujuan pendidikan lingkungan hidup adalah membentuk manusia yang memiliki perilaku bertangungjawab dalam berinteraksi dengan lingkungan hidup. Pendidikan lingkungan hidup juga merupakan dasar-dasar pendidikan dalam proses pemecahan masalah lingkungan hidup dengan dasar filosofis keseluruhan, kelestarian, peningkatan dan pemeliharaan agar semuanya menjadi lebih baik (Fien, 1993).

Seorang individu yang mempunyai sikap positif terhadap kelestarian alam, akan cenderung berperilaku yang mendukung kelestarian alam. Mengingat penyebab kerusakan alam adalah perilaku manusia, maka solusi yang tepat bagi masalah tersebut tentunya harus berawal dari perubahan perilaku (Sadava, 1997). pendidikan ekologi ini adalah karakteristik 
individu yang peduli lingkungan diantaranya adalah mempunyai masa kecil yang introspektif dengan lingkungan dan mendapatkan pengaruh dari role model (Sadava, 1997). Hal ini menunjukkan bahwa mengenalkan anak dengan isu kerusakan alam sejak dini dan memberi contoh perilaku yang ramah lingkungan akan mendorong anak menjadi individu yang peduli pada kelestarian alam.

\section{Metode Kegiatan}

Metode pendekatan yang digunakan untuk memecahkan permasalahan yang dialami oleh guru-guru di Desa Tempur, Kabupaten Jepara dalam laporan penelitian tentang efektivitas pengabdian masyarakat adalah:

a. Ceramah, metode ini digunakan untuk menyampaikan materi awal terkait dengan konsep bencana, pendidikan bencana dan respon psikososial.

b. Diskusi kelompok terarah, digunakan untuk memantapkan konsep pembuatan buku pendidikan bencana secara bersama dan interaktif

c. Curah pendapat, metode ini digunakan untuk menggali masukan dari guru-guru yang tinggal di daerah rawan bencana

d. Tanya jawab, digunakan untuk mendapatkan imbal balik, memberikan dan mendapat masukan serta penjelasan terkait dengan bencana dan respon psikososial serta kondisi ekosistem yang ada di Desa Tempur.

\section{Hasil}

\section{Persiapan Pelatihan ke Guru di Desa Tempur, 14 Mei 2016}

Satu bulan sebelum pelaksanaan pelatihan, tim pengabdian melakukan kontak dengan pihak Yayasan Wali Songo, yang dikenal sebagai lembaga pendidikan yang menaungi sekolah MI Al Anwar dan MTs Mathali'ul Huda di Desa Tempur, Kabuparen Jepara untuk melaksanakan pengabdian. Penyiapan mulai dari teknis pelatihan yang akan dilakukan seperti: perijinan, peserta dan jadwal pelatihan. Setelah mendapat kepastian tanggal dan jam serta tempat pelatihan maka tim pengabdian menghubungi pembicara yang akan terlibat dalam pelatihan.

\section{Pelatihan Pendidikan Bencana dan Respon Psikososial, Rabu 8 Juni 2016}

Ketua tim pengabdian, Mochamad Widjanarko dan anggota, Dian Wismar'ein pada hari Rabu, 8 Juni 2016 jam 09:00 - 14:00 mengadakan Pelatihan Pendidikan Bencana dan Respon Psikososial Guru di Desa Tempur, Kabupaten Jepara. Kegiatan ini bekerjasama dengan Yayasan Wali Songo, Tempur dan MRC (Muria Research Center) Indonesia.

Peserta yang mengikuti pelatihan oleh 28 guru MI Al Anwar 01 dan 02 serta 15 guru MTs Mathali'ul Huda. Tujuan Pelatihan ini adalah Pertama, guru mendapatkan keahlian untuk mengenal ancaman bencana yang ada di Desa Tempur, Kabupaten Jepara. Kedua, 
guru dapat mengurangi tekanan psikologis pada siswa-siswi yang tinggal di daerah rawan bencana. Ketiga, terdapatnya buku pendidikan bencana yang akan dibuat oleh guru, buku pendidikan bencana ini dapat dijadikan model pada guru-guru yang bertugas di lereng pegunungan Muria dalam penyusunan muatan lokal pengajaran pendidikan bencana.

Pemateri pelatihan adalah Pertama, Agus Hendratno, seorang staf pengajar di Fakultas Teknik Geologi UGM yang membawakan makalah berjudul Identifikasi dan Penanganan Tanah Longsor. Kedua, M.Zainuddin dari BPBD (Badan Penanggulangan Bencana Daerah) Kabupaten Jepara yang memberikan pengertian dasar mengenai bencana. Ketiga, Femi Noviyanti, Wartawan Jawa Pos-Radar Kudus dengan makalah Jurnalisme Lingkungan dalam Bencana dan Keempat, Mochamad Widjanarko, staf pengajar di Fakultas Psikologi Universitas Muria Kudus yang memberikan materi bertema Respon Psikososial Bencana: Psychological First Aid.

\section{Penyiapan Materi Konsep Buku Pendidikan Bencana, 26 Juli 2106}

Penajaman materi konsep buku pendidikan bencana dengan metode diskusi kelompok terarah dilakukan pada hari Selasa, 26 Juli 2016 jam 19:30 di salah satu rumah seorang guru, yaitu Sanusi Anwar. Dalam pertemuan tim kecil perwakilan guru MI Al Anwar 01 dan 02 serta guru MTs Mathali'ul Huda diberi penajaman materi mengenai tanah longsor oleh Alvian, mahasiswa Pascasarjana Teknik Geologi UGM, kemudian difasilitasi oleh ketua tim pengabdian, Mochamad Widjanarko.

Para guru diajak untuk memetakan kebutuhan buku yang dimaksud, mulai dari tujuan, manfaat buku dan isi yang berkaitan dengan tema-tema yang akan dituliskan, sebelum itu fasilitator membagi dalam dua kelompok, yaitu guru MI/SD untuk bahan buku MI/SD dan kelompok yang lain yaitu guru MTs/SMP untuk membahas bahan buku MTs/SMP (tercantum dalam bagan di bawah ini). Sebelum acara selesai jam 22:30-an, disepakati pada Hari Jumat, 2 September 2016 untuk berkumpul lagi dengan membawa bahan buku yang sudah menjadi tanggungjawab masing-masing guru.

\begin{tabular}{|l|l|}
\hline \multicolumn{2}{|c|}{ Identifikasi Naskah Buku Pendidikan Bencana } \\
\hline \multicolumn{1}{|c|}{ MI / SD } & \multicolumn{1}{c|}{ SLTP / MTs } \\
\hline Bahasa sederhana dan menarik & Narasi lebih banyak daripada gambar \\
\hline Ada gambar & Problem solving \\
\hline Kejadian nyata & Ilustrasi permainan / TTS \\
\hline Kutipan ditulis sumbernya & Ada contoh penelitian kecil \\
\hline Foto & Foto \\
\hline
\end{tabular}




\section{Penyusunan Buku Pendidikan Bencana, 2 September 2016}

Untuk penyusunan buku pendidikan bencana lanjutan pada hari Jumat, 2 September 2016, pertemuan dilakukan jam 19:00 di ruang kelas dengan agenda mengumpulkan naskah dan kompilasi naskah dengan contoh sket atau gambar di dalam buku, desain TTS (teka-teki silang) lingkungan, penyusunan data pribadi serta masukan untuk perbaikan buku sebelum naskah terkumpul semua. Jam 21:30 pertemuan selesai dengan agenda lanjutan, tahapan kompilasi naskah dan sket atau gambar pada hari Jumat 30 September 2016.

\begin{tabular}{|l|l|l|}
\hline \multicolumn{3}{|c|}{ Naskah Buku Pendidikan Bencana } \\
\hline \multicolumn{1}{|c|}{ Tema } & \multicolumn{1}{|c|}{ Penulis MI } & \multicolumn{1}{c|}{ Penulis MTs } \\
\hline Tanah longsor & P. Mahfud Aly & P. Sutrisno \\
\hline Banjir bandang/sungai & P. Arif Wahyudi & P. Irhammudin \\
\hline Hutan & P. Parno & P. Anwar \\
\hline Puspa dan Satwa & P. Kiswantoro & P. Sulhani \\
\hline Sampah & P. Suparkam & P. Suhud \\
\hline
\end{tabular}

\section{Editing Naskah Buku Pendidikan Bencana}

Sabtu, 17 September 2016 ketua tim pengabdian, Mochamad Widjanarko dan anggota tim pengabdian, Dian Wismar'ein merekap semua naskah guru MI dan guru MTs serta menghubungi pihak editor untuk proses editing awal naskah guru MI terlebih dahulu.

Senin, 26 September 2016 ketua tim pengabdian, Mochamad Widjanarko dan anggota tim pengabdian, Dian Wismar'ein berdiskusi berkaitan dengan naskah-naskah guru MTs untuk proses kelengkapan naskah dan edit serta memberikan beberapa catatan terkait dengan naskah.

\section{Kover Buku Pendidikan Bencana}

Jumat, 16 September 2016 ketua tim pengabdian, berkomunikasi dengan desainer sket atau gambar, yaitu Anton Noor Ferdi untuk pembuatan kover buku pendidikan bencana dari naskah guru MI, dengan tenggat waktu tanggal 10 Oktober 2016. Kemudian pada hari Senin, 20 September 2016 ketua tim pengabdian, kembali berkomunikasi dengan desainer kover buku MTs, Murod Ihsan Kamal untuk pembuatan kover buku pendidikan bencana dari naskah guru MTs, dengan tenggat waktu tanggal 15 Oktober 2016.

Kover buku ini diperlukan untuk memberikan gambaran secara utuh dan luas kondisi sebenarnya di Desa Tempur sehingga setelah melihat kover, buku akan menarik untuk dibaca. 


\section{ISBN Buku Pendidikan Bencana}

Setelah semua naskah dan kover buku lengkap maka pada hari Selasa, 15 November 2016 ketua tim pengabdian mengajukan permintaan ISBN buku pendidikan bencana melalui Badan Penerbit Universitas Muria Kudus. Kamis, 24 November 2016 ISBN buku pendidikan bencana keluar.

\section{Cetak Buku Pendidikan Bencana}

Setelah melewati proses editor naskah dari ketua tim pengabdian dan editor luar, serta kelengkapan buku seperti kover dan ISBN maka naskah karya guru MI dinyatakan layak untuk diterbitkan menjadi buku. Akhir bulan November 2016 buku pendidikan bencana karya guru MI Al Anwar 01 dan 02 masuk cetak dan di bulan Desember 2016 telah jadi.

Sedangkan untuk naskah buku guru MTs Mathali'ul Huda dikarenakan belum selesai dalam melakukan editing naskahnya, akan menyusul dicetak tidak lama lagi setelah melalui proses yang sama seperti dalam penerbitan buku pendidikan bencana karya guru MI Al Anwar 01 dan 02.

\section{Simpulan}

1. Guru di Ml Al-Anwar dan MTs Mathali'ul Huda telah mendapatkan keahlian untuk mengenal ancaman bencana yang ada di daerahnya dan bisa memiliki kemampuan mengurangi tekanan psikologis pada siswa-siswi yang tinggal di daerah rawan bencana, seperti di Desa Tempur, Kabupaten Jepara.

2. Guru di Ml Al-Anwar dan MTs Mathali'ul Huda di Desa Tempur, Kabupaten Jepara telah membuat buku pendidikan bencana.

\section{Saran}

Saran untuk kegiatan laporan penelitian tentang efektivitas pengabdian masyarakat selanjutnya yaitu

1. Diperlukan pendampingan dan pelatihan lanjutan untuk meningkatkan pengetahuan para guru terkait dengan pendidikan bencana dan respon psikososial.

2. Pendidikan bencana dapat dijadikan muatan lokal di sekolah rawan bencana. 


\section{DAFTAR PUSTAKA}

BNPB. (2010). Jurnal Dialog Penanggulangan Bencana. Jakarta: Badan Penanggulangan Bencana Nasional (BNPB) Volume I Nomor 1, Oktober 2010.

Fien, J. (1993). Educational for the Environment. Victoria: Deakin University

Nirarita, E. (1999). Pengembangan Pendidikan Lingkungan Berbasis Masyarakat. Jakarta.

Warta Konservasi Lahan Basah Vol 8 No 2, Agustus.

Sadava, S.W.(1997). Applied Social Psychology: An introduction. In S. W. Sadava \& D. R. McCreary (Eds.), Applied Social Psychology (pp. 1-10). Upper Saddle River, New Jersey: Prentice-Hall

Suara Merdeka. (2004). 26,6 Ribu Hektare Hutan Muria Diindikasikan Kritis. Semarang: Suara Merdeka, 21 September.

Widjanarko, M. \& Nugroho, A. (2010). Kajian Risiko dan kerentanan Atas Kebijakan Pengurangan Risiko Bencana di Kawasan Pegunungan Muria. (Laporan Penelitian Koalisi Muria \& ICCO Belanda, tidak diterbitkan). YLSKaR: Salatiga.

Widjanarko, M. (2012). Psikologi Lingkungan: Teori dan Praktek. Kudus: Badan Penerbit Universitas Muria Kudus

Widjanarko, M dkk (2014). Pengurangan Risiko Bencana: Pendidikan Bencana di Kawasan Pegunungan Muria. Kudus: Muria Research Center (MRC) Indonesia. 